\title{
PROBLEMS AND TEACHING SOLUTIONS FOR STUDENTS' IN LEARNING ENGLISH
}

\author{
Sandra Gunawan', Haris Saputra² \\ ${ }^{1}$ IKIP Siliwangi \\ ${ }^{2}$ IKIP Siliwangi \\ ${ }^{1}$ sandgunawan@gmail.com, ${ }^{2}$ bombsyeah@gmail.com
}

\begin{abstract}
The Indonesian government has recognized the importance of English by including it in the education system for five decades. English has been integrated into secondary school for a long time. English exerts a stronger influence in the modern world and has become an international language. There are also advantages to introducing foreign languages to young students. Therefore, the Indonesian government made a policy to introduce English starting, elementary, middle and high school. At Katapang 1 Junior High School, this policy is optional. That depends on the demands of the school and the community. Schools and communities are responsible for providing teachers, curriculum and facilities. The teacher is one of the most important parts of the educational discourse and teaching and learning process in school. The two research questions formulated are: 1) what problems are faced by teachers in teaching? 2) how they find out the solutions? These questions urged the study to conduct a research at Katapang 1 junior high school. Three English teachers were chosen as respondents. In qualitative descriptive method, the interview was implemented to collect the data. As a result the teachers believe that providing good teaching materials can increase positive outcomes for student, the implementation program for teaching English at Katapang 1 Junior High School was very good as a stage of introducing foreign languages before they continued to higher education.
\end{abstract}

Keywords: English Teaching, Problems, Solutions

\section{INTRODUCTION}

Teaching English in Indonesia began at the time after Indonesian Independence. Various curricula and methods have been developed to improve students' ability to mastering English. Even the results are still not felt maximally in making students able to communicate well through the language. Various problems and factors are the background why the results achieved are not as expected. The school has the authority regarding English language subjects included as one of the extra conversations that began to disappear which was taught at Katapang 1 Junior High School based on consideration and needs of the situation and conditions of both the parents and the community itself. This policy has a positive impact on both the community and the school that organizes the program. Over the past few years, there has been an increasing tendency for schools to implement English language teaching programs through extra conversation activities at Katapang 1 Junior High School.

In its development, this program faces problems - both from the school and from the teacher. One of the obstacles faced is the unavailability of syllabus specifically for English subjects. Although as an extra conversation subject, but English must still have its own syllabus. The government, in this case the national and primary education ministries, do not provide English language syllabus. The task was fully handed over to each province to make its own syllabus 
according to the situation and conditions in the area. Another problem is teaching methods and strategies by teachers that are not in accordance with student development.

English teaching material must be fun and interactive. Therefore the material and methods provided must be in accordance with the development of students. The teachers said that they could use interesting songs, puzzles, games and pictures during the teaching and learning process. According to Damayanti (2016) in Cahyati, Parmawati, and Atmawidjaya (2019) teaching and learning English as a foreign language has different learning situations, such as limited time allocated to English lessons, large class size, students ${ }^{\text {ee }}$ low motivation, and formfocused exams. Dunn (1983) says that young learners are very easy to improve their language skills through the right games for their age. However, not all games for young students are suitable for them. Therefore the task and obligation of the teacher to be able to select suitable games for them is in accordance with the cognitive, physical, and emotional level of the child. The results of the data also show that teachers believe that student textbooks should be colorful in order to attract students' attention and motivation. Greene and Petty (1967) strongly support this opinion. They say that colorful and interactive images make students interested and curious, adding to their motivation to learn more about the material. It is also added that students will find it easier to memorize vocabulary when they see something interesting. In Frost, (1967) opinion that young mental learners will be very interested in seeing the real object. The object will also be very helpful to develop their imagination.

When respondents were asked whether during the learning process in the class they emphasized an integrated language skills approach or only emphasized one or several specific aspects. The results of the data obtained indicate that they themselves have different opinions. I think their differences are due to the limitations of teaching materials and methods of the respondents.

In general, teachers argue that the emphasis on teaching materials must be limited to certain aspects. This is because the time provided is very limited and the number of students is very large. However, according to the researchers themselves by emphasizing the ability of students on certain aspects, the results to be obtained are not optimal. As stated by Greene and Petty (1967) that the purpose of language learning must emphasize all language skills. Learning to write, read, speak and listen must be taught in an integrated manner

The introduction of English is very important. There are several reasons behind this program that must continue. The first reason is that English is a language that is very important in the international world, especially in the current era of globalization. English is used as a medium of communication with other people from various countries. According to Crystal (2003) that English is spread out and is used almost a quarter of the world's population and continues to grow to one and a half trillion in the early 2000s. The second reason is that by mastering English, people will easily enter and be able to access the world of information and technology. With the introduction of English at Katapang 1 Junior High School, students will know and know the language early. Therefore they will have better basic knowledge before proceeding to a higher level of education.

According to the guidelines for the outline of basic education in Indonesia, the aim of basic education in Indonesia is to prepare students for basic knowledge earlier before moving on to higher education. (Website of the Ministry of National Education, 2004). The last reason is for parents and teachers to provide provisions for students that by mastering English, they can provide more open opportunities to develop themselves in order to get better opportunities to face competition in employment and careers in the future. The opinion of Pennycook (1995) 
that English has become a very decisive tool for the continuation of education, employment and social status of the community.

Finally, the main conclusion of the reason for teaching English at Junior High School is to provide a lot of knowledge on vocabulary mastery so that if students continue their education to a higher level they will not experience difficulties because, the main focus in teaching English according to respondents is mastery of vocabulary especially the extra conversations that are beginning to disappear. By mastering many vocabulary students can easily master other language skills.

Hence, in this occasion we will look at the obstacles faced above, what other problems have arisen faced by teachers during the process of teaching English at Katapang 1 Junior High School and how they overcome the problems.

\section{METHOD}

This research method used qualitative method by outlining the opinions of teachers regarding the problems they face in teaching English at Katapang 1 Junior High School. This study was conducted in Katapang 1 Junior High School. It is about perception of English teacher in terms of the management, perception, and the English teachers were considered to be the key participants for collecting the data interview.

The instrument used in collecting the data of this study were the questionnaires for the English teachers. According to Brown (2001: 6, cited in Apsari and Yana, 2015), questionnaires are any written instruments that presents respondents with a series of questions or statements to which they are to react either by writing out their answers or by selecting from among existing answers. The types of questionnaires were use as the guideline, the things that being quested to find the data, but the interviewing mostly going directionally and proportionally in free communication.

The results of the data obtained will be described narratively or descriptively as one of the prominent factors of the research using qualitative methods.

\section{RESULTS AND DISCUSSION}

Problems Faced by Teachers and How They Deal with them.

\section{Professional Skills}

From the data obtained by the teachers, they expressed their confidence that they were worthy and had professional expertise to teach English at Katapang 1 Junior High School. In general, respondents already have English language education qualifications and through training and English language courses. This is important and appropriate as stated by Brooks (1967) that an English teacher at Katapang 1 Junior High Schoolmust have expertise in English or have attended training to teach students at Katapang 1 Junior High School. Even so, I myself think that they still have to improve their abilities especially in terms of understanding children's habits in learning foreign languages. Therefore training or workshops are still very much needed. On the other hand, the attention of the government, schools and the community must be increased especially regarding the status of honorarium teachers so that this program can take place well. 


\section{Implementation of Teaching in the Classroom}

From the data obtained shows that respondents generally have problems regarding the implementation of classroom teaching. They all expect a pleasant atmosphere during their teaching. What happened was far from their expectations. In language teaching the number of students should be limited. But the fact is that in the classroom there are 50 people or more students so that it does not create an ideal atmosphere. However, this can actually be overcome by dividing students into groups or dividing them into pairs. Johnson (1994: 185) says that there are three advantages to dividing students into groups:

1. Creating an atmosphere of interaction between students and students

2. Change the culture of students from individual work to work in one group.

3. Make a more varied atmosphere so that students can show their abilities to the fullest.

Another expert, Dunn (1983), argues that in one class it should be inhabited between 24 and 30 students. For Katapang 1 Junior High School students usually need more attention. Students expect that they can be more individually considered given their young age. The availability of textbooks for teachers and students is also a supporting factor for the success of this program. The data obtained shows that all teachers use textbooks as their guide in providing teaching material. But some teachers have problems because of the lack of available textbooks for them. Not all students have textbooks so they have to share with other students. From the results of observations in other schools it was found that the availability of textbooks is only available in private schools with very good quality. The problems mentioned above are also added by the teacher not having a guide to which books are feasible and meet the standards to be used as learning material in the classroom.

The unavailability of textbooks in schools can hinder or reduce the motivation of students and teachers. One way to reduce the problem is to provide material that they knew very much before. As an example of learning material related to their daily activities, the introduction of basic technology practice tools at home and school. One of the things that supports it is Ratte (1967: 279) who says foreign language learning will be very useful if teaching materials are related to things - daily activities, or using real media so that it increases students' curiosity and learning motivation. Another opinion from Hamalainen (1967) who said that the way to increase student motivation in learning is to use appropriate teaching media such as films, body movements, globe, images of tape recorders.

Another important thing to note is the problem of placing tables and chairs in class. In traditional classes students usually sit on a bench that is lined up and the teacher explains the lesson in front of the class. In this situation the expected results are not optimal. Therefore schools and communities help each other to provide good class facilities so that student activities in the classroom can take place smoothly. Dunn (1983) said the placement of tables and chairs in the classroom must be able to be arranged in such a way that the interaction of students with teachers and students with students can take place well.

\section{School and Community Participation}

From the results of the data obtained, respondents generally expressed dissatisfaction with school participation and the community. Teachers generally state that schools should be responsible for fulfilling teaching equipment and facilities in schools. They have to do other work besides teaching. From the teacher's side, they can stop teaching, if there are more promising offers from other parties. If this happens, the continuity of this program will be a question mark. 
Another problem is the lack of teaching media. Teachers must prepare teaching media that indirectly increase their own expenses. Nevertheless the teacher was very happy to teach his students. The actual school obligations that can provide an ideal teaching atmosphere. Another disadvantage is the absence of language laboratory facilities that have begun to disappear (none) and libraries that meet the standards at the Katapang 1 Junior High School.

\section{CONCLUSION}

From the data obtained and discussed in the previous section, four main conclusions can be obtained: First, the teachers believe that providing good teaching materials can increase positive outcomes for students. They argue that students will be more happy to learn and be motivated when the material taught about their daily events, time, season, objects that are in school and at home. Moreover, the material makes them happy and interactive. This is obtained if the material is through songs, puzzles, game stories and pictures. Secondly, the implementation program for teaching English at Katapang 1 Public High School was very good as a stage of introducing foreign languages before they continued their higher education. However, because only five respondents could be interviewed, researchers could not give generalizations about this. More problems are found in the implementation of the teaching and learning process in the classroom. There are two main reasons for the problem. The first is the teacher's weakness in dealing with students' problems in the classroom. The second is the availability of limited facilities from the school. Therefore the teacher feels that the involvement of the school and the community has not helped much in implementing this program. So that the teachers really expect the involvement of the school and the community, especially parents in the success of the English language teaching program at Katapang 1 Junior High School through the provision of adequate facilities and facilities for teachers to teach these subjects, in order to support the grade XII students' scores with perfect results.

\section{ACKNOWLEDGMENTS}

We thank the family, parents, friends and lecturers who have given us support both morally and materially, so that we can complete and publish our journal.

\section{REFERENCES}

Apsari, Y., \& Yana, Y. (2015). Teachers'techniques And Problems In Teaching Reading. P2m Stkip Siliwangi, 2(2), 217-233.

Brooks. (1967). Literature In Language Teaching. Falmer Press.

Cahyati, S. S., Parmawati, A., \& Atmawidjaja, N. S. (2019). Optimizing English Teaching And Learning Process To Young Learners (A Case Study In Cimahi). Journal Of Educational Experts (JEE), 2(2), 107-114.

Crystal. (2003). English As A Global Language. Cambridge University Press.

Dunn. (1983a). Beginning English. The Macmilan Press.

Dunn. (1983b). Beginning English With Young Children. The Macmillan Press Limited, London.

Frost. (1967). Readings In Foreign Languages For The Elementary School. Blaisdell Publishing Company.

Greene, \& Petty. (1967). Developing Language Skills In The Elementary School. Boston : Allyn And Bacon, Inc.

Hamalainen. (1967). English Teaching And Learning. Department Of English Education. 
Johnson. (1994). Foreign Language \& Literature. Cohen.

Pennycook. (1995). English In The World. Cambridge University Press. 